\title{
Russiske energiressurser i Arktis: økonomi og politikk
}

\author{
Ann Karin Larssen * \\ Cand. polit, høgskolelektor ved Luftkrigsskolen i Trondheim
}

\begin{abstract}
Russian Energy Resources in the Arctic: Economy and Policy
This article examines the economic and political importance of Russia's energy resources. Economic dependence is confirmed, but political decisions made since the turn of this century have made Russia less vulnerable to outside economic and political pressures. Due to the sharp fall in oil prices, and recent international sanctions, the authorities will give priority to enhanced oil recovery from older fields in Western Siberia and the opening of new fields in the area, with Russia remaining onshore in the Arctic. Finally, as to military and economic relations between Russia and Norway in the Arctic, the article finds that military tensions are increasing, while pragmatism prevails in economic relations.
\end{abstract}

Keywords: Oil and gas, Arctic, Russian energy policy, Russian economy, Russia, Norway

Fra 2014 har russisk energisektor vært rammet dobbelt hardt, både av nedgang i prisene på det internasjonale oljemarkedet og av internasjonale sanksjoner i kjølvannet av konflikten i Ukraina. Dette får selvsagt økonomiske konsekvenser for Russland og det har betydning for forholdet mellom Russland og Norge i Arktis, både økonomisk og militært.

Arktis kom for alvor på den internasjonale dagsorden i 2008 da det amerikanske geologiske selskapet U.S. Geological Survey (USGS) publiserte en studie der det ble anslått at store mengder av verdens såkalt «uoppdagede» olje- og gassressurser skulle befinne seg i Arktis.

Året før, i august, hadde en russisk ekspedisjon plantet et russisk flagg på havbunnen under polpunktet. Dette ble oppfattet som nok et tegn på et mer selvhevdende Russland, slik også president Vladimir Putins tale på sikkerhetskonferansen i München i februar samme år ble tolket. For Norge ble Russlands økende fokus på Arktis først og fremst merkbart da Putin i august 2007 annonserte at landet ville gjenoppta toktene med strategiske bombefly fra baser lenger sør i Russland og opp mot Arktis og dermed norske nærområder.

At det var drivverdige ressurser i Arktis, var ikke nytt for Russland som allerede i en årrekke hadde drevet utvinning i området, dog ikke på sokkelen. Allerede i 2001 hadde Russland levert krav om utvidet sokkel til FNs Sokkelkommisjon, men ble

^Kontaktinformasjon: Ann Karin Larssen. Email: Ann.Larssen@1ksk.mil.no 
bedt om å komme tilbake med et bedre underbygget krav. Det gjorde Russland i 2015.

Denne artikkelen har tre forskningssiktemål som også gjenspeiles i artikkelens struktur. For det første å undersøke ikke bare den økonomiske betydningen av olje- og gassressursene for Russland, men også de politiske målsettingene som ligger til grunn for en aktiv russisk energipolitikk. For energiressursene i Russland handler om mer enn økonomisk inntjening. Hovedvekten vil ligge på olje, både fordi Russland eksporterer en større andel av oljen enn gassen og fordi det er mer å tjene på eksport av denne energiressursen. For det andre vil artikkelen se på Arktis' plass i denne energipolitikken. Til sist vil artikkelen kaste et kort blikk på det konkrete forholdet mellom Russland og Norge i Arktis, både militært og økonomisk.

Kildegrunnlaget for artikkelen vil i tillegg til faglitteratur være en rekke russiske primærkilder i form av ulike politiske strategier som kan fortelle noe om målsettingene for russisk energisektor i stort og for Arktis spesielt. Hvordan målsettingene slår ut $\mathrm{i}$ praksis vil undersøkes gjennom bruk av russisk statistikk og internasjonal faglitteratur.

\section{Energiressursenes økonomiske betydning}

Historien om Russland som produsent og eksportør av energi er en historie om økende økonomisk avhengighet som oppsto i sovjettiden. Inntektene ga hard valuta til Sovjetregimet og ble blant annet brukt til innkjøp av vestlig teknologi og korn (Gaidar 2007; Gustafson 2012: 47).

Mens Sovjetunionen produserte 353 millioner tonn råolje i 1970, var tallet økt til i overkant av 603 millioner tonn i 1980 og nådde toppen i 1988 med nesten 624 millioner tonn (569 millioner tonn for den russiske delen) (Goldman 2010: 35-36). Produksjonen ble så halvert fram til midten av 1990-tallet (303 millioner tonn i 1996) før den så smått begynte å vokse igjen på tampen av tiåret og nådde en foreløpig postsovjetisk topp i 2015 med drøyt 533 millioner tonn råolje (Gustafson 2012: 17; Energidepartementet u.d.a).

Dette fikk konsekvenser for eksportert mengde råolje som i sovjettiden nådde toppen i 1989 med 263 millioner tonn (for hele Sovjetunionen). Mengden ble halvert fram til midten av 90-tallet og deretter nådde en foreløpig topp i 2004 med drøyt 260 millioner tonn (Gustafson 2012: 49; Sentralbanken u.d.a). Deretter har eksportmengden gått noe ned, men økte fra 2014 til 2015 da Russland eksporterte drøyt 244 millioner tonn råolje (ibid.).

Inntektene fra salg av olje ble selvsagt også påvirket av prisene på verdensmarkedet. Når prisene falt, måtte import finansieres gjennom låneopptak i utlandet. Prisene på det internasjonale markedet begynte å falle i 1981 og kollapset i midten av tiåret (Goldman 2010: 35-36). Det samme gjorde Sovjetunionens inntekter fra eksport av olje (Gaidar 2007: 5; Topoilnewus u.d.). I 1989 var den sovjetiske staten så å si bankerott (Åslund 2013: 88; Gustafson 2012: 47). Den samme historien gjentok seg for den russiske staten i det påfølgende tiåret. Fra 1997 til 1998 ble oljeprisene kraftig redusert fra et allerede lavt nivå, denne gangen som følge av Asiakrisen, en finanskrise som 
startet i Asia sommeren 1997 og blant annet førte til kraftig fall i råvareprisene på verdensmarkedet. I 1998 kunne ikke Russland betjene utenlandsgjelden sin.

For den russiske staten var det gjennom 1990-tallet et problem at inntektene fra energisektoren i liten grad kom staten til gode i form av for eksempel skatteinntekter. Thane Gustafson anslår at på slutten av 90-tallet evnet den russiske staten å skattlegge bare mellom en fjerdepart og en tredel av inntektene fra olje. Riktignok bidro oljeindustrien med $25 \%$ av skatteinntektene til staten, men store deler av inntektene fra olje ble unndratt beskatning (Gustafson 2012: 259). Gjennom så å si hele 1990tallet var de russiske føderale budsjettene underfinansierte og den økonomiske veksten var også på minussiden før trenden snudde i 1999 (Åslund 2013: 94-95; Verdensbanken u.d.a).

På slutten av 1990-tallet ble det på ny vekst i prisene på verdensmarkedet, men både i 2009 og etter 2014 ble russisk økonomi på nytt rammet av kraftige fall i oljeprisene. Som følge av finanskrisen i 2008 falt oljeprisene kraftig med påfølgende negativ økonomisk vekst $(-7,8 \%)$ for Russland i 2009 . Den samme historien gjentok seg i 2014 da oljeprisene på det internasjonale markedet ble mer enn halvert i løpet av kort tid. Russisk økonomisk vekst gikk ned i $2014(0,7 \%)$ og ble negativ i 2015 $(-3,7 \%) .2016$ ser ut til å ende med negativ vekst på $-0,6 \%$ før veksten igjen forventes å bli svakt positiv fra 2017 (Verdensbanken u.d.b). Virkningene for russisk økonomi ble imidlertid mindre dramatiske etter de to siste prisfallene som følge av bevisst politikk for å beskytte russisk økonomi mot effekten av kraftige fall i prisene på olje.

Olje og gass har de senere årene bidratt til $50 \%$ av inntektene til Russlands føderale budsjett, og dette er en kraftig vekst fra 2004 da det tilsvarende tallet var $30 \%$ (Sabitova 2015: 426). Olje- og gassressursenes andel av de totale eksportinntektene var $68 \%$ i $2013,{ }^{1}$ mot $38 \%$ i 1998 (EIA 2014; Gustafson 2012: 187).

Mye tyder imidlertid på at vekstpotensialet i økonomien basert på energi tømmes. Mens Russland hadde negativ økonomisk vekst gjennom stort sett hele 1990-tallet, var den økonomiske veksten gjennom Putins to første perioder som president gjennomsnittlig 6,8\%. Etter negativ økonomisk vekst i 2009 ble den økonomiske veksten igjen positiv, men på et langt lavere nivå enn i årene forut for 2009. Veksten etter 2009 var nedadgående til den igjen endte på minussiden i 2015. Dette til tross for kraftig oppgang i oljeprisene etter det forutgående stupet i 2008 og fram til 2014.

\section{Den politiske betydningen av energiressursene}

1990-tallets økonomiske problemer var utgangspunktet for en artikkel Vladimir Putin publiserte i 1999, før han ble statsminister og deretter president i Russland for første gang. Hvordan skape en bærekraftig utvikling av russisk økonomi og redusere Russlands økonomiske tilbakeliggenhet, var spørsmålet han stilte i artikkelen

\footnotetext{
${ }^{1}$ Brutt ned i større detalj fordeler de $68 \%$ seg som følger: $14 \%$ naturgass, $33 \%$ råolje, $21 \%$ petroleumsprodukter og $32 \%$ uspesifisert «andre» (EIA 2014).
} 
«Mineral Resources in the Strategy for Development of the Russian Economy» (Putin i Balzer 2006). ${ }^{2}$

Ifølge Putin lå løsningen i de ikke-fornybare naturressursene. Forutsetningen var at staten tok tilbake den strategiske ledelsen av råvaresektoren, gjennom reguleringer og gjennom endringer av skattesystemet. Staten skulle ha kontroll over de strategiske ressursene ikke bare med utgangspunkt i en profittbasert tankegang, men også på grunn av politiske målsettinger som kunne nås på basis av inntektene: Ressursene dekket Russlands egne behov, de ga inntekter til staten (inkludert valutainntekter), ressursene var basis for landets militære makt, for sosial stabilitet blant annet på grunn av arbeidsplasser, og for integrasjon av Russland i verdensøkonomien (Putin i Balzer 2006).

Med en bærekraftig økonomisk utvikling ville Russland igjen bli en stormakt:

In terms of a general conclusion it follows that the existing socio-economic conditions, and also the strategy for Russia's exit from its deep crisis and restoration of its former might on a qualitatively new basis demonstrate that the condition of the natural resource complex remains the most important factor in the state's development in near term (Putin i Balzer 2006: 54).

Putin overtok som president ved utgangen av 1999 og kom til makten i starten av en økonomisk oppgangsperiode, basert på økte priser på energi på verdensmarkedet og økt russisk produksjon. ${ }^{3}$ Økte priser og økt produksjon av olje i Russland var selvsagt ikke Putins fortjeneste, men ble et heldig sammenfall i tid for Putin og kretsen rundt ham. Dette var politikere med vilje til å bruke de potensielt store inntektsmulighetene dette bød på for staten. Den økonomiske oppgangsperioden skyldtes i stor grad endrede råvarepriser på verdensmarkedet, åpning av nye oljefelt og at russiske oljeselskap med hjelp av vestlig teknologi og kompetanse klarte å øke utvinningen i gamle felt (Gustafson 2012: 189). Putins artikkel kan derfor leses som et forvarsel om at staten i større grad ønsket kontroll over olje- og gassektoren, og at en større andel av inntektene skulle kanaliseres tilbake til staten og være basis for å styrke denne. Man kan selvsagt kritisere måten noe av dette ble gjennomført på, men resultatet var at Putins målsettinger delvis ble oppnådd i de påfølgende årene.

I årene etter Putins artikkel har det blitt godkjent flere energistrategier som gjentar de politiske målsettingene: I 2003, i $2009^{4}$ og et Utkast (ennå ikke godkjent) i 2015. A styrke den russiske staten hjemme og ute på basis av energiressursene er et poeng som først og fremst uttrykkes eksplisitt i energistrategien fra 2003. I strategien fra 2009 (2010) og Utkastet til ny energistrategi (2015) ser imidlertid dette ut til å være

\footnotetext{
${ }^{2}$ Harley Balzer (2005: 215) antyder at artikkelen utgitt i Putins navn kan ha vært forberedt av folk rundt senere finansminister Aleksej Kudrin. Putin utga imidlertid artikkelen i sitt navn og har dermed gått god for innholdet, samtidig som artikkelen er uttrykk for ideer i kretsen rundt Putin. ${ }^{3}$ Produksjon og eksport av energi er selvsagt ikke hele forklaringen på veksten i russisk økonomi etter 90-tallet, men en vesentlig del. Gustafson (2012: 360) anslår at omtrent halvparten av veksten det første tiåret etter at Putin kom til makten, har direkte sammenheng med inntekter fra salg av råvarer.

${ }^{4}$ Strategien ble godkjent i 2009, men i artikkelen vil det bli henvist til en engelsk utgave fra 2010 .
} 
tonet ned, og fokuset i mye større grad lagt på målsettinger og utfordringer for energisektoren som sådan. Det er selvsagt mulig at dette vil forandres når den endelige strategien vedtas.

Å styrke staten kan bety flere ting, det handler både om at energiressursene kan brukes til å gi innflytelse og til å styrke forsvaret. For eksempel kan man lese at energiressursene kan være et virkemiddel i russisk innenriks- og utenrikspolitikk og er avgjørende for landets geopolitiske innflytelse (Energistrategi 2003: 4, 60). I praksis er det velkjent at Russland først og fremst overfor sitt såkalt «nære utland» bruker prisfastsetting og transitt til å skaffe seg innflytelse. Eksempler på dette er «gasskrigene» med Ukraina i 2006 og 2009 (Orttung \& Øverland 2011). Men dette er altså en målsetting som i senere energistrategier er tonet ned. Gasskrigene viste seg å så tvil om Russland som en sikker og forutsigbar leverandør av gass til Europa og viste for alle praktiske formål at press på transittland kan slå negativt ut for russiske interesser.

Å bruke energiressursene til å styrke det militære forsvaret kommer til uttrykk i alle de tre energistrategiene og er en gjenkjennbar målsetning fra Putins artikkel:

The long-term state energy policy aims to protect the rights and legal interests of citizens and business entities, ensure state defense and security (Strategi 2010: 24; se også Strategi 2003: 16).

I praksis et det åpenbart en sterk samvariasjon mellom størrelsen på russiske forsvarsbudsjett og inntekter fra olje og gass. Selv om det vanskelig lar seg giøre å sammenlikne det sovjetiske forsvarsbudsjettet og det russiske, er det grunnlag for å si at reduksjonene i forsvarsbudsjettene startet allerede før oppløsningen av Sovjetunionen. I 1989 hevdet Mikhail Gorbatsjov at budsjettet hadde blitt frosset i 1987 (New York Times 1989). Deretter fulgte en nedadgående trend i bevilgningene til det russiske forsvaret gjennom 90-tallet før den snudde i 1999. Først etter 2011 kom forsvarsbevilgningene opp på samme nivå som det de var i 1992 (Hakvåg, Hove \& Sendestad 2012: 29).

På grunn av de økonomiske problemene som fulgte nedgangen i oljeprisene i 2014, ble forsvarsbudsjettet i 2015 mindre enn først planlagt, men økte likevel sammenliknet med året forut, ifølge Sipri (2016). I mars 2016 forelå et forslag om å redusere forsvarsbudsjettet for det inneværende året med $5 \%$ (Lowe \& Golubkova 2016).

Gjenkjennbart er også tanken om selvforsynthet og i forlengelsen av dette, energisikkerhet. Russland har energiressurser nok til å dekke eget innenlandsk forbruk og er ikke avhengige av andre for å få slike strategisk viktige forsyninger. Store mengder av det Russland produserer av olje og gass går til eget forbruk. Russland var på andreplass når det gjaldt innenlands forbruk av gass og femte største forbruker av olje per 2012 (IEA 2014: 97, 125). Generelt forbruker Russland mer av gassen enn av oljen de produserer, henholdsvis nesten $70 \%$ av gassen og 52,5\% av oljen i 2012 (Godzimirski 2013: 1). Russland har dessuten kapasitet til å produsere mye mer gass enn det hjemmemarkedet og eksportmarkedet trenger (IEA 2014: 81).

Denne selvforsyntheten er del av «energisikkerheten» som omtales gjennomgående $i$ energistrategiene og som igjen anses å være en sentral del av den nasjonale sikkerheten 
(Energistrategi 2003: 17; Energistrategi 2010: 28, Utkast 2015: 14; Nasjonale sikkerhetsstrategi 2015: pkt. 60-61), slik det uttrykkes i Energistrategi 2010:

Energy security is one of the most important components of the national security. Energy security is the country's security, that of its citizens, society, state and economy from threats to reliable supply of fuel and energy (Energistrategi 2010: 28).

Energisikkerhet synes å handle både om å dekke internt forbruk og å sikre staten inntekter fra salg internt og eksternt. I sin tur er dette avhengig av Russland klarer å opprettholde produksjonsnivået og oppnå en fordelaktig pris på verdensmarkedet.

Gitt at eksport av energi utgjør $68 \%$ av alle russiske eksportinntekter er energi dermed også hovedkilden til valutainntekter for Russland (EIA 2014). Dette er midler som betaler for russisk import. Som i 1999 skal det fortsatt være Putins overbevisning at hard valuta er en garanti for Russlands finansielle selvstendighet (Pismennaya \& Andrianova 2016). Da Putin overtok makten i Russland, på tampen av 1999, utgiorde de internasjonale reservene 12,5 milliarder amerikanske dollar, i juli 2016 var beholdningen 392,8 milliarder dollar (Sentralbanken u.d.b). ${ }^{5}$ De internasjonale reservene ble kraftig redusert gjennom 2014 og ytterligere gjennom 2015, men har gjennom 2016 vist en svak vekst. ${ }^{6}$

Russland har overskudd på handelsbalansen totalt sett. ${ }^{7}$ De samlede eksportinntektene gikk imidlertid ned fra 2014 (496,8 mrd. dollar) til 2015 (341,5 mrd. dollar) blant annet som følge av nedgangen i oljeprisene og internasjonale sanksjoner (Sentralbanken u.d.c). Det er også verdt å merke seg at til tross for at både produksjonsmengden og eksportmengden av råolje gikk noe opp fra 2014 til 2015, viser verdien målt $\mathrm{i}$ dollar en kraftig nedgang, fra rundt 154 milliarder dollar til rundt 90 milliarder dollar (Sentralbanken u.d.a). ${ }^{8}$ Når Russland fortsatt har handelsoverskudd skyldes dette også et tilsvarende fall i russisk import fra 2014 (307,9 mrd. dollar) til 2015 (193 mrd. dollar) (Sentralbanken u.d.c). Spørsmålet er selvsagt hvordan dette vil påvirke russisk økonomi på lengre sikt, ettersom store deler av russisk import består av vestlig teknologi.

I forlengelse av ideen om en mer bærekraftig økonomi og finansiell selvstendighet kvittet Russland seg med store deler av utenlandsgjelden sin i 2005-2006. Deler av de økte inntektene fra slutten av 1990-tallet ble brukt til å redusere gjeld etablert i sovjettiden og gjennom 90-tallet fra $96 \%$ av BNP til $9 \%$ (Finn 2006). Fortsatt har Russland per 2015 relativt lav statsgjeld sammenliknet med svært mange

\footnotetext{
${ }^{5}$ Toppåret var før finanskrisen sommeren 2008 da reservene utgjorde nesten $600 \mathrm{mrd}$. dollar.

${ }^{6}$ Ved utgangen av 2013 utgjorde de internasjonale reservene ca. $510 \mathrm{mrd}$. dollar, ved utgangen av 2014 var tallet redusert til ca. $385 \mathrm{mrd}$. dollar. Ved utgangen av 2015 var tallet $368 \mathrm{mrd}$. dollar og ved utgangen av september 2016 var tallet $398 \mathrm{mrd}$. dollar (Sentralbanken u.d.b). En av forklaringene på den kraftige reduksjonen i 2014 var forsøket på å opprettholde den russiske rubelens verdi overfor amerikanske dollar.

${ }^{7}$ Tall oppgis tilbake til og med 1994 og viser overskudd i hele perioden.

${ }^{8}$ Til sammenlikning var eksportverdien av gass i 2014 54,7 mrd. dollar og i 2015 41,9 mrd. dollar (Sentralbanken u.d.d).
} 
vestlige land, målt som prosent av BNP utgjør den i underkant av $18 \%$, men er økende (Trading Economics u.d.a). ${ }^{9}$ Målt i amerikanske dollar er imidlertid den russiske statens utenlandsgjeld redusert, fra 56 milliarder dollar i januar 2014 til 50 milliarder dollar i januar 2016 (Finansdepartementet u.d.a). Etter som russisk BNP krymper vil imidlertid gjelden målt som prosent av BNP øke.

Russiske myndigheter brukte også deler av inntektene fra olje og gass fra 2004 til å bygge opp stabiliseringsfond. ${ }^{10}$ Mens Reservefondet skal dekke opp budsjettunderskudd når olje- og gassprisene går under budsjettert nivå, skal det Nasjonale velferdsfondet sikre det russiske pensjonssystemet. Størrelsen på Reservefondet har vist en stadig nedadgående trend fra starten av 2015 og fram til oktober 2016 da det utgjorde $2,6 \%$ av BNP (Finansdepartementet u.d.b). ${ }^{11}$

Det føderale budsjettet i Russland har vært et underskuddsbudsjett fra 2012, slik budsjettene stort var gjennom hele 1990-tallet. Størrelsen på underskuddene har økt hvert år og spesielt fra 2014 til 2015 (Finansdepartementet u.d.c). ${ }^{12}$ Målt i prosent av BNP utgjorde underskuddet mindre enn $3 \%$ i 2015, og det er ikke mye (Trading Economics u.d.b).

Det Nasjonale velferdsfondets størrelse målt i rubler og som del av BNP økte gjennom 2014 og 2015, og utgjorde 6,6 \% av BNP per januar 2016 (Finansdepartementet u.d.d). ${ }^{13}$ Store deler av fondet er bundet opp giennom investeringer og støttetiltak for russiske banker, infrastrukturprosjekt og for eksempel støtte til blant annet Rosneft (CNBC 2016).

Statsfinansene gir foreløpig ikke inntrykk av at situasjonen er kritisk for den russiske staten som sådan. For russiske borgere, regioner og russiske selskap er situasjonen mer kritisk, uten at vi skal komme nærmere inn på dette her.

Det er belegg for å hevde at russisk økonomisk politikk i en viss forstand har vært vellykket. Ikke fordi Russland har blitt mindre avhengige av inntekter fra olje og gass, tvert i mot, men i stedet for å forbruke alle inntektene har deler av dem blitt brukt til å bygge buffere for vanskelige økonomiske tider. Dermed har den russiske staten klart seg langt bedre etter raset i oljeprisene i 2008 og 2014, enn det som var tilfelle både på slutten av 80-tallet og 1990-tallet. Russland er i en posisjon der de er mindre sårbare for press fra omverden, både av markedsmessig og politisk art, enn det de ellers ville vært. Antakeligvis handler ikke dette bare om en økonomisk tankegang, men er

\footnotetext{
${ }^{9}$ Russlands totale utenlandsgjeld er imidlertid langt større dersom vi også inkluderer privat sektor og statseide selskap. Russlands totale utenlandsgjeld ble likevel redusert fra 599 til 515,3 mrd. dollar i 2015 (Miller 2016; RBTH 2016).

${ }^{10}$ Stabiliseringsfondets midler ble fra 2008 overført til henholdsvis Reservefondet og det Nasjonale velferdsfondet. Deler av fondene består av valuta. Akkumulering i fondene er knyttet både til skattlegging av innenlandsk produksjon og av eksportavgifter.

${ }^{11}$ Per 1. januar 2014 utgjorde Reservefondet $2859 \mathrm{mrd}$. rubler, 1 . januar 2015 var tallet $4945 \mathrm{mrd}$. rubler, 1. januar 2016 var tallet 3640 mrd. rubler, per oktober 2016 var tallet i overkant av 2000 mrd. rubler.

${ }^{12}$ Underskuddsbudsjett var også tilfelle i 2009 og 2010. Målt i rubler var underskuddet 334,7 mrd. rubler i 2014 og $1961 \mathrm{mrd}$. rubler i 2015.

${ }^{13}$ Per. 1.januar 2014 var tallet 2900 mrd. rubler, $1.1 .154388 \mathrm{mrd}$. rubler, 1. januar 2016 var tallet 5227 mrd. rubler.
} 
samtidig utrykk for en buffermentalitet i større forstand, en grunnleggende mistillit til omgivelsene og en overbevisning om at Russland er omringet og sårbart. Det er imidlertid grenser for den russiske økonomiens utholdenhet, og hvordan situasjonen vil påvirke framtidig inntjeningsevne er høyst usikker.

Det er også interessant å merke seg at problemene ikke bare er knyttet til nedgangen i oljeprisene på det internasjonale markedet og Vestens sanksjoner mot Russland. Til tross for at prisen per fat på Urals råolje økte fra under 40 dollar på det laveste i 2008, til godt over 100 dollar per fat fra $2011 \mathrm{og}$ fram til prisfallet sommeren 2014 (Topoilnews u.d.) har Russland operert med fallende økonomisk vekst, underskuddsbudsjett og forbruk av bufferne landet har bygd opp siden 2000-tallet.

\section{Energiressursene i Arktis}

Mens Putins artikkel fra 1999 ikke nevnte ressursene i Arktis, gjøres det både i energistrategiene og de arktiske strategiene en kobling mellom de økonomiske og politiske målsettingene og ressursene i nevnte område. Det samme gjøres i mer sikkerhetsfokuserte dokumenter som også inneholder passuser om energiressursene $\mathrm{i}$ Arktis og betydningen for Russland. ${ }^{14}$

En fortsatt vellykket gjennomføring av de tidligere nevnte politiske og økonomiske målsettingene krever at olje- og gassproduksjonen holdes oppe, og at prisene ikke synker på det internasjonale markedet. Mens sistnevnte ikke kan påvirkes av Russland, pågår det en iherdig innsats for å holde innenlandsk produksjon oppe.

I sovjettiden foregikk leting, utvikling og utvinning av energiressurser i hovedsak sør for polarsirkelen. Vest-Sibir har gjennom mange tiår vært den største gass- og oljeproduserende regionen i landet, et område som strekker seg både sør og nord for polarsirkelen. Noen av de virkelige store gassfeltene i Vest-Sibir ligger imidlertid ved polarsirkelen på fastlandet, med blant annet Jamburg i Jamalo-Nenetsk (Claes \& Moe 2014: 108). Oljeutvinningen i Vest-Sibir har tradisjonelt ligget lenger sør, i Khanty-Mansijsk. Samotlor-feltet er et av de virkelig store oljefeltene i Russland, og har vært i produksjon fra slutten av 1960-tallet. Per 2002 foregikk $56 \%$ av all russisk oljeproduksjon i Khanty-Mansijsk, og $86 \%$ av all russisk gassproduksjon i Jamalo-Nenetsk (Kryukov \& Moe 2014: 126). ${ }^{15}$ Disse olje- og gassfeltene som har blitt utvunnet fra 1970-tallet og framover, har imidlertid nådd produksjonstoppen for lengst.

Gjennom det første tiåret etter oppløsningen av Sovjetunionen var det lite letevirksomhet etter olje og gass og få nye felt kom i produksjon (Gustafson 2012: 60-61; Claes \& Moe 2014: 108). Lite tydet på at Arktis skulle bli en region av økonomisk betydning for Russland. Det økonomiske potensialet ble undervurdert i Jeltsin-perioden og først og fremst sett som en byrde og kilde til ulike sosioøkono-

\footnotetext{
${ }^{14}$ Arktiske strategier har blitt publisert henholdsvis i 2001, 2008 og 2013. Med «sikkerhetsfokuserte dokumenter» siktes det til Maritime doktriner (2001 og 2015), den siste Militærdoktrinen (2014) og den Nasjonale sikkerhetsstrategien (2015).

${ }^{15}$ Per 2013 bidro Vest-Sibir samlet med $60 \%$ av total oljeproduksjon (EIA 2015).
} 
miske problemer (Konyshev \& Sergunin 2014: 326-7). Denne tankegangen ble gradvis endret fra 2000-tallet.

I russisk Arktis er det nå både felt i produksjon og påviste reserver:

Approximately 61 large oil and natural gas fields have been discovered within the Arctic Circle. (...) Fifteen of these 61 large Arctic fields have not yet gone into production; 2 in Russia. (...) Forty-three of the 61 large Arctic fields are located in Russia. Thirty-five of these large Russian fields (33 natural gas and 2 oil) are located in the West Siberian Basin. 15 of the eight remaining large Russian fields, five are in the Timan-Pechora Basin, two are in the South Barents Basin, and one is in the Ludlov Saddle (Budzik 2009: 4).

I tillegg kommer de såkalt «uoppdagede» ressursene, det vil si antatte, men ennå ikke påviste ressurser. I 2008 publiserte U.S. Geological Survey (USGS) en mulighetsstudie over uoppdagede ressurser i hele det sirkumpolare Arktis (USGS 2008). Det ble antatt at omkring $22 \%$ av verdens uoppdagede ressurser befant seg $i$ Arktis, hvorav $13 \%$ av den uoppdagede oljen.

Basert på USGS sine anslag om uoppdagede ressursene ressurser, har James Henderson og Julia Loe (2014: 5) gjort følgende beregning over andelen uoppdagede ressurser i Arktis som kan befinne seg i russiske områder, både til lands og under havbunnen:

The breakdown by country shows that Russia has by far the largest share of Arctic resources. The West Siberian shelf alone contains $32 \%$ of the total (...) of Arctic resources, while other Arctic regions in Russia account for another $26 \%$, meaning the country's overall share is $58 \%$.

Mesteparten av de uoppdagede ressursene er med andre ord russiske. Et annet viktig poeng er at det i den russiske delen av Arktis først og fremst antas å være gass, ikke olje, og at ressursene i hovedsak befinner seg offshore og ikke på land (Laruelle 2014: 136; Henderson \& Loe 2014: 23).

Både når det gjelder Russlands utvinning av gass og av olje, har det $i$ de senere år vært en bevegelse nordover, inn i Arktis. Gassutvinningen har beveget seg ut på Jamal-halvøya i Jamal Nenetsk og antas å inneholde $27 \%$ av russiske gassreserver (IEA 2014: 84). Bovanenkovo-feltet, det største gassfeltet på Jamal-halvøya, startet produksjon i 2012. Et anlegg for flytende naturgass (LNG) er også under bygging der og er planlagt ferdig i 2017. Dersom dette lykkes, vil Russlands første LNGanlegg i Arktis komme i drift.

I Timan-Petsjora-området, i den nordvestlige delen av Russland har det også pågått en forflytting nordover og inn i Arktis, fra Komi-republikken der det lenge har vært oljeutvinning, og inn i arktiske Nenets, hvor dette er relativt nytt (Tykkylainen 2003: 158; Claes \& Moe 2014: 107). Trebs og Titov-feltet er planlagt satt i kommersiell produksjon i 2016 (IEA 2014: 135). Samlet ble det i Nenets, Komi og Jamalo-Nenetsk utvunnet 50 millioner tonn olje i 2015 (Staalesen 2016) av en totalproduksjon på drøyt 533 millioner tonn samme år.

Den nyeste utviklingen i russisk Arktis har vært på kontinentalsokkelen. På 1980-tallet ble det gjennomført prøveboring på kontinentalsokkelen i Barentshavet 
(Kryukov \& Moe 2013: 43). Produksjon ble imidlertid ikke iverksatt ettersom ressursene på land lenger sør var i overflod og langt enklere å utvinne. Russlands første arktiske offshore oljeplattform, Prirazlomnaja, sørøst i Barentshavet, ble derfor ikke satt i drift før i 2013 og leverte den første oljen tidlig året etter (Kreml 2014). Produksjonsvolumet her vil vokse i de kommende årene (Henderson 2015: 15).

\section{Framtiden for russisk olje- og gassproduksjon i Arktis}

I 2008 ble omtrent en femtedel av Russlands BNP produsert i Arktis, og regionen sto for $22 \%$ av russisk eksport (Kreml 2008). Utvinning av olje og gass vil naturlig nok utgjøre en vesentlig del av dette. Det er en politisk målsetting at en større andel av russisk BNP etter hvert skal produseres i Arktis (Arktisk strategi 2013: pkt. 36a). Tidlig i 2014 publiserte det russiske Energidepartementet en kortversjon med hovedpunktene av det som skulle bli en ny energistrategi. Kortversionen er siden erstattet av et Utkast (2015). I kortversjonen oppgis en målsetting om at per 2035 skal $5 \%$ av oljen og $10 \%$ av gassen bli utvunnet på den arktiske sokkelen (Energistrategi, hovedpunkter 2014: 22). I Utkastet synes denne konkrete målsettingen å være fjernet. ${ }^{16}$

\section{Tilbudssiden - å opprettholde produksjonen}

Den russiske oljeproduksjonen nådde en foreløpig postsovjetisk topp i 2015 med drøyt 533 millioner tonn, mens naturgassproduksjonen gikk ned fra 2011 til og med 2015 (Godzimirski 2013:1; Energidepartementet u.d.a, u.d.b). Russland eksporterte en større andel av oljen enn av gassen, henholdsvis $47,5 \%$ av oljen og $30,3 \%$ av gassen per 2011 (Godzimirski 2013: 1). ${ }^{17}$

En gjennomgående bekymring i alle de nevnte dokumentene (se for eksempel den Arktiske strategien fra 2001) er frykten for ikke å opprettholde produksionen og påstanden om at feltene i de tradisjonelle utvinningsområdene på land i Vest-Sibir tømmes både når det gjelder olje og gass. I Energistrategien godkjent i 2009 (2010: $62-3$ ) oppgis at $65-75 \%$ av mengden gass i de tre store feltene i Vest-Sibir (Medvezje, Urengoj og Jamburg) skal være uttømt og at det samme er gjeldende for omtrent halvparten av russiske oljereserver. ${ }^{18}$ Gjennomgående for både energistrategiene og de arktiske strategiene er at Arktis og sokkelen skal være ett av arvtakerområdene når de tradisjonelle feltene lenger sør i Vest-Sibir tømmes.

Nye felt må settes i produksjon for å holde produksjonsvolumet oppe over tid. På kort sikt er det Timan-Petsjora og Jamal-halvøya som skal bidra til å opprettholde produksjonsmengden. Planen har lenge vært å øke produksjonen i disse områdene og å bevege seg ut på sokkelen. Denne nevnes som ett av de mest lovende områdene

\footnotetext{
${ }^{16}$ Kortversjonen ble antakeligvis publisert tidlig i 2014 og derfor før prisene sank og før sanksjonene ble innført.

${ }^{17}$ Produksjon av olje og gass utgjorde per 2012 omtrent like stor andel av total energiproduksjon i Russland, henholdsvis 39,1\% og 40,6\% (IEA 2014: 17).

${ }^{18}$ Det betyr at produksjonsmengden er sterkt nedadgående, men at det med mer avansert teknologi kan være mulig å øke produksjonen, eller i alle fall sinke den nedadgående trenden.
} 
for utvinning av olje og gass både i energistrategien fra 2003 (Energistrategi 2003: 59) og i 2009 (Energistrategi 2010: 63). I alle energistrategiene gis det inntrykk av at innenfor løpeperioden skal utvinning på sokkelen iverksettes. I Energistrategien fra $2003 \mathrm{er}$ dette perioden fram til 2020 (s. 59, 63, 72), i strategien fra 2009 er perioden forlenget til 2030 (s. 63), og i Utkastet fra 2015 er perioden forlenget til 2035 (s. 36). Tidshorisonten for når Russland skal ut på den arktiske sokkelen forskyves dermed fortløpende og handler åpenbart ikke bare om sanksjonene som ble innført mot Russland i 2014.

Utkastet gir inntrykk av en mer avventende holdning til utvinning på den arktiske sokkelen, i alle fall når det gjelder olje (Utkast 2015: 23, 36). Målsettingen er å opprettholde nivået på oljeutvinning og å øke tilsvarende for gass (Utkast 2015: 36). Heller enn å bevege seg ut på sokkelen, ser det i Utkastet ut til at andre løsninger er mer aktuelle for å opprettholde produksjonsvolumet ennå en tid. De tradisjonelle områdene i Vest-Sibir skal beholdes som hovedområdet for oljeutvinning i Russland, blant annet gjennom å øke utvinningsgraden i allerede produserende felt og åpning av nye. Førstnevnte kan oppnås gjennom bruk av mer avansert utvinningsteknologi som horisontal boring, hydraulisk frakturering og Enhanced Oil Recovery-teknologi (EOR) (Utkast 2015: 36; IEA 2014: 129-30). Målsettingen er å øke oljeutvinningsgraden fra 28 til $40 \%$ når det gjelder konvensjonelle oljeressurser og fra 8 til $15 \%$ når det gjelder såkalt vanskelig utvinnbare ressurser (Utkast 2015: 17). Hydraulisk frakturering er delvis prøvd ut med hell blant annet på Samotlor-feltet, et konvensjonelt oljefelt i Khanty-Mansijsk (EIA 2012). Gjennomsnittlig oljeutvinningsgrad i verden er $30 \%$, i Norge er den $46 \%$ (IEA 2014: 130), så Russland ligger åpenbart et stykke bak, og enda mer dersom tallene som oppgis er for optimistiske.

En av fordelene med å øke utvinningen i allerede etablerte områder og finne nye felt der er at infrastruktur for leting, utvinning og transport allerede er tilstede og vil bidra til å senke kostnadene sammenliknet med utvikling om nye områder, som for eksempel sokkelen i Arktis.

Utvinning av skiferolje er også en mulighet som nevnes i Utkastet. Basjenovformasjonen består av skiferolje og påstås viktig for å bidra til å opprettholde produksjonen i sørlige deler av Vest-Sibir og altså ikke i Arktis (Utkast 2015: 36).

Dersom noe av dette lykkes, vil sokkelen i Arktis kunne vente enda en stund. Utspillet i Utkastet er nok både et forsøk på å tilpasse planene til det internasjonale sanksjonsregimet, men også resultat av de lave oljeprisene som reduserer lønnsomheten for høykostprosjekt som utvinning på sokkelen i Arktis. Samtidig er det en erkjennelse i Utkastet om at sokkelen ikke kan unngås i lengre perspektiv, dersom Russland skal være i stand å produsere tilstrekkelig olje og gass ved utløpet av strategiens periode, 2035 (Utkast 2015: 53).

\section{Hinder for utvinning og tilbudssiden $i$ Arktis}

Både tiltakene for å øke produksjonsvolumet i tradisjonelle områder og utvinning på sokkelen i Arktis står imidlertid overfor en rekke hinder.

Ett hinder er det internasjonale sanksjonsregimet. Sanksjonene som ble innført mot Russland i 2014 etter annekteringen av Krim og innblandingen i Øst-Ukraina har blitt forlenget flere ganger, av både USA og EU. ${ }^{19}$ Foreløpig er sanksjonene 
forlenget til henholdsvis mars og januar 2017. Sanksjonsregimets hensikt er ifølge det norske Utenriksdepartementet «(...) å redusere Russlands langsiktige evne til å utnytte teknisk avanserte løsninger for utvinning av landets oljeressurser» (2014). Så lenge sanksjonene varer vil det $\mathrm{i}$ bestemte områder og med behov for en bestemt type kompetanse og teknologi være reduserte muligheter til letevirksomhet og utvinning av olje.

Deler av sanksjonsregimet er direkte rettet mot oljeleting og -utvinning i havområdene nord for polarsirkelen. Russland har ikke kompetanse og teknologi til slik virksomhet og er derfor avhengig av å få dette utenfra. ${ }^{20}$ Sommeren 2014 ble det gjennomført leteboring i Karahavet, der Rosneft samarbeidet med amerikanske ExxonMobil. På grunn av sanksjonene ble prøveboringen avsluttet og senere ikke gjenopptatt. Den første prøveboringen viste at det på Pobeda-feltet er mulige drivverdige funn av både olje og gass (Pinchuk \& Astakhova 2015). Inntil videre er det satt en stopper for leting og utvikling av felt til havs i Arktis.

Sanksjonsregimet er også rettet mot oljeleting og utvinning av skiferolje med bruk av hydraulisk frakturering. Her skal hovedproblemet være at Russland mangler ekspertise, teknologi og reservedeler som rammes av sanksjonene. Det betyr at russisk ønske om å utvikle Basjenov-formasjonen i sørlige deler av Vest-Sibir får problemer så lenge sanksjonene vedvarer. De utenlandske selskapene som samarbeidet med russiske selskap på dette området har som følge av sanksionene trukket seg ut.

På grunn av sanksjonene vil både utvinning på sokkelen i Arktis og utvikling av skiferolje-prosjekt være svært vanskelig. Det betyr at Russland i hovedsak må konsentrere seg om å øke utvinningsgraden i felt som allerede er i produksjon og å åpne nye felt for å opprettholde produksjonen fram til tidlig 2020-tallet. James Henderson mener dette er mulig, men avhenger av en rekke usikre faktorer (2015: 52):

The actual outcome will depend upon a number of key assumptions including the impact of the rouble devaluation, the ability of Russia to replace imports of goods embargoed under sanctions, the additional impact of sanctions on the ability of companies to raise finance, and the willingness of the Russian government to offer direct financial support.

Også uten sanksjonsregimet er det $\mathrm{i}$ øyeblikket en rekke hinder for russisk utvinning på den arktiske sokkelen på grunn av det store prisfallet på olje fra 2014. Utvinning på sokkelen er høykostprosjekt og det må stilles spørsmål ved om det vil være økonomisk lønnsomt. Det internasjonale energibyrået (IEA) anslår at det vil koste mellom 40 og 100 amerikanske dollar per fat olje å utvinne ressursene på sokkelen (Laruelle 2014: 138). Estimatet er veldig bredt, men med dagens oljepriser under 50 dollar per fat må det stilles spørsmål ved lønnsomheten. Det russiske Energidepartementet, på sin side, har hevdet at utvinning i Arktis kan være lønnsomt selv med dagens priser (Fomtsjenkov 2015).

\footnotetext{
${ }^{19}$ Norge forholder seg til EUs sanksjonsregime.

${ }^{20}$ Rosneft og Gazprom har monopol på utvinning av ressurser til havs. Ifølge Gustafson (2012:

472) er det bare Lukoil som har erfaring til havs, men ikke i arktiske strøk.
} 
Kanskje er det et poeng at på russisk sokkel i Arktis er det først og fremst gass og ikke olje. Per 2003 befant omtrent tre firedeler av de anslåtte oljereservene seg på land, mens gassreservene var omtrent likelig fordelt mellom land og sokkel (Energistrategi 2003: 57). Ifølge Henderson og Loe var $80 \%$ av de uoppdagede ressursene i russisk Arktis anslått til å være gass (2014: 23, 25). Når $68 \%$ av russiske eksportinntekter kom fra olje og gass per 2013, er det et vesentlig poeng at inntektene fra råolje utgjorde $33 \%$, mens inntekter fra gass utgjorde bare $14 \%$ (EIA 2014). Kanskje kan sokkelen også vente av denne grunn, det er mer lønnsomt å utvinne olje enn gass.

På den annen side kunne man tenke at gitt den økonomiske avhengigheten av olje og gass økonomisk og politisk, vil russiske myndigheter være mer risikovillige når det gjelder leting og utvinning av ressurser på sokkelen, i alle fall på lengre sikt. Det estimeres uansett 10 til 15 år fra første prøveboring til et oljefelt er i drift i Arktis (Henderson \& Loe 2014: 37) og sanksjonene bidrar til ytterligere forlenging av dette tidsperspektivet.

Til tross for en uttalt målsetting gjennom flere energistrategier om å bli uavhengige av utenlandsk kompetanse og teknologi har dette åpenbart ikke skjedd, heller ikke i tiden forut for sanksjonene. Denne avhengigheten omtales interessant nok som en trussel mot energisikkerheten som igjen er en del av statssikkerheten (Utkast 2015: 13). Resultatet av sanksjonspolitikken og mangelen på egen teknologi og kompetanse, fører til at Russland vil satse på gamle felt og områder og la sokkelen i Arktis vente. Av samme grunner vil også utvinning av skiferolje måtte utsettes.

\section{Etterspørselssiden}

Gitt at russisk økonomi ikke klarer å fri seg fra energiavhengigheten er det ikke nok at Russland klarer å opprettholde produksjonsnivået, det er også avgjørende at det finnes kjøpere, at det er etterspørsel, og denne vil variere påvirket av en rekke faktorer. Mens den globale finanskrisen i 2008 førte til lavere etterspørsel, og dermed lavere priser, etter både olje og gass på grunn av lavere økonomisk aktivitet, er nedgangen i priser fra 2014 resultat av overproduksjon. Prisen på Urals råolje ${ }^{21}$ sank fra 108,93 dollar per fat i januar 2014 til 46,58 dollar per fat i januar 2015 (Rapoza 2015). ${ }^{22}$

En faktor som kan påvirke den framtidige etterspørselen er den nylig inngåtte Paris-avtalen i 2015. Avtalen ble nådd gjennom konsensus mellom 195 land. Målsettingen med avtalen er å holde økningen i den globale gjennomsnittstemperaturen under 2 grader celsius og å holde utslipp av klimagasser nede. I andre halvdel av dette århundret er målsettingen utslippsnøytralitet (Luomi 2016). Når utslippene skal kraftig ned, er det naturlig å tenke at dette vil gi nedgang i etterspørselen etter fossilt brennstoff. For Russland, som er verdensledende i både produksjon og eksport av olje og gass, kan dette bli en utfordring.

\footnotetext{
${ }^{21}$ Russisk eksportolje er en blanding av russisk råolje fra ulike felt i Russland, av ulik kvalitet, og omsettes under betegnelsen Urals råolje. Den russiske referanseoljen er av litt dårligere kvalitet og billigere enn den norske Nordsjø-oljen som omsettes som referanseoljen Brent Blend.

${ }^{22}$ Se også graf «prisutvikling Urals 2002 til 2013» i IEA (2014: 18).
} 
British Petroleum (BP) og U.S. Energy Information Administration (EIA) er blant flere som i 2016 har publisert rapporter med forsøk på å si noe om framtidig energiforbruk. Begge hevder at vekst i verdens befolkning og global økonomisk vekst med påfølgende høyere levestandard, vil føre til mer transport av mennesker og varer. Dette brukes som begrunnelser for at både olje- og gassforbruket vil øke globalt, men først og fremst utenfor Europa (BP 2016; EIA 2016). Begge anslår videre at den største veksten i etterspørsel vil være etter naturgass, mer moderat for olje, og at henholdsvis i 2035 og 2040 vil fossilt brennstoff utgjøre henholdsvis $80 \%$ og $78 \%$ av det totale energiforbruket mot $86 \%$ i 2014 (BP 2016: 15; EIA 2016: 1). Det anslås at den største veksten i etterspørsel vil komme utenfor OECD, fra blant annet Kina og India (EIA 2016: 37; BP 2016: 21, 31).

Per 2014 gikk henholdsvis $72 \%$ av russisk råolje til europeiske land (EU og Hviterussland), og $26 \%$ til land i Asia. Samme år gikk $90 \%$ av russisk naturgass til europeiske land (EU og Hviterussland) (EIA 2015). Eksportert mengde har imidlertid gått ned til EU etter en foreløpig topp i 2006 (Franza 2016:3).

Russiske myndigheter forsøker å løse nedgangen på det europeiske markedet gjennom å rette seg mer mot forventet vekst i det asiatiske markedet både for olje og gass (Utkast 2015: 8). I den forbindelse vil det være gunstig med mer utvinning på sokkelen i Arktis. Ressursene i Arktis, inkludert på sokkelen, kan bidra til å forenkle russiske ønsker om å selge mer til asiatiske land. Gitt både det dårlige forholdet mellom vestlige land og Russland og utsiktene til at etterspørselsveksten vil komme i Asia, vil en kombinasjon av utvinning i Arktis og frakt langs den nordlige sjørute være gunstig. Dette er også noe av bakgrunnen for russiske planer om å åpne et LNGanlegg på Jamal-halvøya i 2017. Finansieringen skal være ordnet på tross av sanksjonene, men det har også vært stilt spørsmål om Russland vil få tilgang på nødvendige kjølesystemer for å få anlegget i drift (Goodman \& Potter 2016). Dersom dette lykkes vil det for Russland også ha den ønskede effekt å bli mindre avhengig av transittland, først og fremst Ukraina. Samtidig vil avhengigheten av Europa minske. Dette krever imidlertid enorme investeringer i utbygging av infrastruktur, og dette er selvsagt også en faktor som vil påvirke lønnsomheten i prosjektene. Samtidig er det en forutsetning at Russland er i stand til å hevde seg i den økende konkurransen på det internasjonale gassmarkedet ettersom totalproduksjonen antas å øke.

EIA forventer at oljeprisene vil nå 80 dollar fatet igjen innen slutten av inneværende tiår (EIA 2016: 20). Utkastet til ny energistrategi forteller at også i Russland er det forventninger om økte oljepriser på lengre sikt (Utkast 2015: 74) og økt produksjon. I november 2016 ligger prisen per fat Urals på i overkant av 44 amerikanske dollar (Topoilnews u.d.). Det russiske statsbudsjettet forutsetter en pris på 50 dollar per fat (Tass 2016) Det anslås at under gunstige forhold kan den totale eksporten av russiske energiressurser øke med $20 \%$ i perioden 2015-2035 (Utkast 2015: 10).

Mer økt LNG og frakt på kjøl vil i større grad giøre også gassmarkedet, som oljemarkedet, mer globalt og prisene bli fastsatt som spotpriser. ${ }^{23}$ Spesielt gassforbruket antas å øke, hvilket er gunstig for Russland som har verdens største 
reserver. Når prisene øker vil lønnsomheten ved utvinning også på sokkelen i Arktis bli bedre.

\section{Norge og forholdet til Russland i Arktis}

Russisk aktivitet i Arktis har selvsagt betydning for norske interesser, både av økonomisk og militær art. Området har gjennom mange tiår hatt militær-strategisk betydning for Russland, men den militære tilstedeværelsen og aktiviteten gikk kraftig ned i årene etter oppløsningen av Sovjetunionen. I de senere årene har denne trenden snudd, delvis som følge av forbedring av russisk økonomi som har giort det mulig å modernisere det russiske forsvaret, men også fordi forholdet til Vesten har kjølnet. I tillegg har Arktis fått økende økonomisk betydning og dette synes å forsterke den militære betydningen av området.

I de tidligere nevnte sikkerhetsfokuserte dokumentene kobles energiressursene og Arktis opp mot behovet for å beskytte ressursene militært. I den nyeste Militærdoktrinen (2014: pkt. 32) kan man for første gang lese at det er en militær oppgave å sikre Russlands nasjonale interesser i Arktis: altså militær sikkerhet, regionen som strategisk ressursbase og den nordlige sjørute (Arktisk strategi 2008: pkt. 4). I de arktiske strategiene er dette et poeng helt fra den første utgaven i 2001, men uten at det da fikk praktiske konsekvenser. Endringen i tilstedeværelse og aktivitet begynte så smått i 2007 med gjenopptakelse av toktene med strategiske bombefly opp til Arktis fra baser lenger sør i Russland (Kreml 2007). Denne aktiviteten hadde nesten vært fraværende etter oppløsningen av Sovjetunionen. Russiske myndigheter erklærte ny permanent tilstedeværelse i Arktis i 2013 (RT 2013). Russland har begynt gjenåpningen av flystriper fra den kalde krigens dager, har så langt etablert to arktiske brigader, utplassert nyere og flere militære kapasiteter og øvelsene har blitt hyppigere (Sputniknews 2015). Tilstedeværelsen og aktiviteten er imidlertid langt lavere enn under den kalde krigen og skal dekke et enormt område; omtrent halvparten av den arktiske kystlinjen er russisk.

Russiske myndigheter beskriver Arktis som et område preget av kamp om ressurser, at stadig flere stater, arktiske og ikke-arktiske, retter sin oppmerksomhet mot dette området (Kreml 2014). Som ellers i Russland er det også i Arktis frykt for terroraksjoner. Eksempelvis har det blitt pekt på olje- og gassproduksjonsanlegg, lasteterminaler og rørledninger som mulige terrormål (Kreml 2014). Sommeren 2014 ble det gjennomført en kontraterrorøvelse der scenarioet var terrorangrep mot oljeinstallasjoner og i oktober 2015 øvde en av de arktiske brigadene på å slå tilbake terrorangrep mot flyplassen på Novaja Zemlja (Barentsobserver 2015; Staalesen 2014).

\footnotetext{
${ }^{23} \mathrm{Når}$ en større andel av verdens gassressurser omsettes som flytende naturgass (LNG) og fraktes med båt, vil dette gjøre gassmarkedet mer globalt. Prisene vil i større grad bli bestemt av dagens marked og ikke som resultat av forhåndsinngåtte, langsiktige avtaler slik det blir når gassen fraktes i rørledninger og markedene dermed er mer regionale.
} 
Det synes politisk viktig å iverksette økt tilstedeværelse raskt både for å sikre hevd i området og som basis for inntekter til framtidige føderale budsjett. Virksomheten på sokkelen er ennå lav, men økende aktivitet her og større bruk av den Nordlige sjørute kan bidra til ytterligere militær tilstedeværelse i området.

Som følge av sanksjonene mot Russland fra 2014 har Norge suspendert alt militært samarbeid med Russland med unntak av søk og redning, kystvakt- og grensevaktsamarbeid. I øyeblikket er det lite som tyder på at forholdet mellom Norge og Russland militært vil bli bedre i Arktis. Under toppmøtet i NATO i Warszawa i juli 2016 fikk norske myndigheter gjennomslag for ønsket om økt oppmerksomhet om Nord-Atlanteren (NATO 2016: pkt. 23 i sluttkommunikeet). Hvordan dette vil bli omsatt i praksis gjenstår å se, men det borger ikke for fortsatt militær lavspenning. En konflikt $\mathrm{i}$ et område langt vekk fra Norge har dermed fått militære konsekvenser i Arktis, og vi har også sett at deler av sanksjonsregimet i kjølvannet av konflikten i Ukraina er rettet mot Arktis.

Det er lite som tyder på at Russland har planer om å annektere områder $\mathrm{i}$ Arktis som landet etter folkeretten ikke har krav på, i alle fall dersom vi skal ta offisielle uttalelser på alvor. I Ilulissat-erklæringen fra 2008 forplikter de fem arktiske kyststatene seg til å overholde Havrettskonvensjonen (Ilulissaterklæringen 2008). Det er også et poeng at mesteparten av de uoppdagede ressursene i Arktis allerede er under nasjonal kontroll. I praksis har Russland i 2011 inngått en delelinjeavtale i 2010 med Norge i Barentshavet og Russland har sendt inn et fornyet krav i 2015 om utvidet sokkel til FNs Sokkelkommisjon, etter at kravet fra 2001 ble underkjent på grunn av mangelfull dokumentasjon. Overlappende krav med Danmark og Canada vil avgiøres med diplomatiske virkemidler (Staalesen 2015).

På det økonomiske området får man inntrykk av at pragmatismen råder $\mathrm{i}$ forholdet mellom Russland og Norge på energisiden. Russland har innført importforbud for en rekke jordbruksprodukter og fisk fra EU, USA, Australia, Canada og Norge. Ifølge Aale (2014) er det Norge som ble hardest rammet økonomisk av de russiske motsanksjonene i 2014. Eksporten fra Russland til Norge økte imidlertid i 2015 som følge av omlasting av olje i transitt fra Russland (Emberland 2015).

I utgangspunktet skulle man tro at Norge og Russland kan ha stor gjensidig økonomisk nytte av hverandre i Arktis. Både på norsk og russisk side er det ressurser på havbunnen. Mens Russland har hoveddelen av ressursene, har Norge svært god kompetanse på utvinning offshore, også i arktiske strøk med Snøhvit-feltet (Statoil 2009) og det russiske Okhotskhavet. Sistnevnte ligger riktignok ikke nord for polarsirkelen, men har klimatiske forhold som i Arktis.

I forbindelse med avklaring av grenselinjen mellom Norge og Russland ble det innledet et strategisk partnerskap mellom Rosneft og Statoil. I 2012 ble det inngått en større samarbeidsavtale mellom de to selskapene. Avtalen innebar at selskapene var «blitt enige om et program for utveksling og utvikling av kompetanse og teknologi relevant for arktiske strøk samt for ukonvensjonell leting og produksjon» (Statoil 2012).

Rosneft skulle få andeler i Statoils lisenser på norsk sokkel. Som resultat av tildelinger i 22. konsesjonsrunde i 2013 fikk Rosneft / RN Nordic Oil andel i en av 
Statoils lisenser (fire felt) i Barentshavet. Etter at sanksjonene trådte i kraft i august 2014, har Statoil og Rosneft boret i den norske delen av Barentshavet (Statoil 2014).

I 23. konsesjonsrunde som ble avklart våren 2016, ble det for første gang tildelt lisenser blant annet i det tidligere omstridte området mellom de to land i Barentshavet. De privateide russiske oljeselskapene Lukoil og Dea, sistnevnte et oljeselskap eid av russeren Mikhail Fridman, fikk begge andeler av utvinningstillatelser (Regjeringen 2016a). ${ }^{24}$ Lukoils andel ligger ved delelinjen til Russland (Regjeringen 2016b). Begge selskap er allerede inne på norsk sokkel som følge av 22. konsesjonsrunde. Rosneft/ $\mathrm{RN}$ Nordic Oil, det russiske oljeselskapet med statlig aksjemajoritet, ble ikke tildelt andeler i 23. runde til tross for at de søkte.

Fordi forholdet til Russland i øyeblikket er kjølig er det grunn til å spørre om det kan ha vært også politiske begrunnelser for å avvise det største russiske oljeselskapet. Kanskje har norske myndigheter i tillegg vurdert at man ikke ønsker å ha Rosneft på begge sider av delelinjen. Samtidig er det et poeng at halvparten av søkerne ikke fikk andeler i lisenser (Andersen \& Taraldsen 2016).

På basis av samarbeidsavtalen med Rosneft fra 2012 har Statoil interesser i en rekke regioner i Russland, deriblant i Arktis både på land og til siøs. Statoil fikk andeler i fire av Rosnefts lisenser offshore i Barentshavet og i Okhotskhavet, og dessuten avtale om tekniske undersøkelser i to russiske felt på land, i Vest-Sibir og sørvest i Russland.

Sommeren 2016 testet de to selskapene produksjonsbrønner i Yamal-Nenetsk med sikte på å få Nord-Komsomolskojefeltet i full produksjon (Pettersen 2016). Feltet ligger i Arktis, men ikke offshore og er derfor lovlig, ifølge norske myndigheter. Statoil vil imidlertid ikke bore i den russiske delen av Barentshavet der selskapet også har et fellesprosjekt med Rosneft på russisk side i det tidligere omstridte havområdet. Fra tidligere er Statoil partner i Kharjaga-feltet i Nenets.

Høsten 2014 uttalte olje- og energiminister Tord Lien at: «De restriktive tiltakene [sanksjonene] handler om tiltak i Russland og ikke i EU eller i Norge» (Moe \& Ask 2014). For alle gode formål betyr det at russiske selskap kan delta i norsk oljeleting på sokkelen i Norge, og Statoil kan også delta i russiske prosjekt i Russland så sant de ikke direkte er i strid med sanksjonene. På det økonomiske området synes det derfor å herske en pragmatisk tilnærming til sanksjonene selv om intensjonen med avtalen mellom Statoil og Rosneft nettopp er teknologioverføring relevant for arktiske strøk og ukonvensjonell leting og produksion.

På begge sider av den nye delelinjen befinner det seg antakeligvis både olje og gass (Ramsdal 2013). Hjalmar Johansen-høyden er det norske navnet, Fedynsky-høyden det russiske. $30 \%$ av alle uoppdagede norske ressurser er antatt å befinne seg i Barentshavet, og mesteparten i nevnte grenseoverskridende område (Laruelle 2014: 143). Delelinjeavtalene tar høyde for eventuelle grenseoverskridende funn, og inntektene fra feltet må deles mellom de to landene. Problemet skal være at Russland mangler teknologi og kompetanse til prøveboring på sin side av delelinjen. På grunn

\footnotetext{
${ }^{24}$ Etter Fridmans oppkjøp av E.ONs oljefelt i Norge, skal Dea nå være den niende største aktøren på norsk sokkel (Teigen 2015).
} 
av sanksjonene kan de heller ikke leie inn vestlig kompetanse. Blokkene på russisk side tilhører halvstatlige Rosneft som har inngått avtaler med en rekke vestlige selskaper.

For norske interesser er økt russisk aktivitet i Arktis et tveegget sverd. Det er en klar samvariasjon mellom størrelsen på inntektene fra russisk oljeproduksjon/-eksport og størrelsen på russiske forsvarsbudsjett, og den pågående generelle moderniseringen av det russiske forsvaret får også ringvirkninger i Arktis. Ett av tyngdepunktene vil som før være Kolahalvøya og de vestlige delene av Arktis, det samme vil være tilfelle for økt aktivitet på russisk sokkel. Ser man rent økonomisk på det hele, kan det imidlertid potensielt være store inntjeningsmuligheter for Norge på russisk sokkel.

\section{Oppsummering}

Lite tyder på et nært forestående sammenbrudd for russisk økonomi, men landet har åpenbart utfordringer på lengre sikt både på grunn av det internasjonale sanksjonsregimet og på grunn av de lave oljeprisene. Spørsmålet er russisk økonomisk utholdenhet.

Russiske myndigheter gjorde noen smarte grep fra 2000-tallet. Lån ble innfridd og det ble bygd opp økonomiske buffere for å unngå at neste oljekrise skulle ramme Russland like hardt som på slutten av 1980- og 1990-tallet. Russisk økonomi er fortsatt minst like sårbar for store svingninger i oljeprisene på verdensmarkedet, men når krisen først rammer er russisk økonomi mer motstandsdyktig. De økte inntektene fra energi har satt Russland i stand til å modernisere forsvaret og gitt de russiske politiske myndigheter selvtillit nok til en mer selvhevdende utenrikspolitikk. Slik sett har russisk energipolitikk lyktes økonomisk og politisk. Den samme mer selvhevdende utenrikspolitikken overfor Ukraina har fra 2014 imidlertid ført til store utfordringer for fortsatt måloppnåelse på lengre sikt, på grunn av sanksjonene.

Utvinning på sokkelen i Arktis er satt på vent, men området på land er allerede viktig for russisk verdiskapning. Spørsmålet er om og når russiske myndigheter vil se seg tvunget til også å utvinne ressursene på havbunnen her. Kombinasjonen av lave oljepriser, høye utvinningskostnader og internasjonale sanksjoner direkte rettet mot utvinning av olje til havs i russisk Arktis borger for at ressursene på havbunnen må vente, kanskje for godt. Skulle strategien med å øke utvinningsgraden i gamle felt samt åpne nye felt i gamle områder lykkes, kan det også bety at sokkelen i Arktis kan vente. Hvordan Russland vil forholde seg til forpliktelsene i Paris-avtalen som trådte i kraft primo november 2016, vil også kunne få betydning for om ressursene på havbunnen i Arktis blir liggende eller ikke.

Bilateralt er forholdet mellom Russland og Norge inntil videre preget av relativ lavspenning $\mathrm{i}$ nord, og når det gjelder utvinning av energiressurser synes pragmatismen å råde overfor sanksjonsregimet på norsk side av delelinjen. En konflikt i et område langt borte fra norske nærområder har ført til et sanksjonsregime som økonomisk ikke er i Norges interesse. Militært kan det i nord være duket for høyere spenning når Russland øker sin aktivitet og får følge av NATO som i sluttkommunikeet fra toppmøtet i Warsawa i 2016 lover å øke sin oppmerksomhet om NordAtlanteren. 


\section{6 | ANN KARIN LARSSEN}

\section{Litteraturliste}

Andersen, Ine \& Lars Taraldsen (2016) «Kun halvparten av oljeselskapene fikk en bit av Barentshavet. Her er taperne». Teknisk Ukeblad 25. mai. Tilgjengelig på www.tu.no/artikler/olje-norge-jublet-over-nye-omraderi-nord-her-er-oljeselskapene-som-tapte-kampen-om-barentshavet/347488. Lesedato 15. august 2016.

Arktisk strategi (2001) «Osnovy gosudarstvennoj politiki Rossijskoj Federatsii v Arktike», 14. juni 2001. Tilgjengelig på www.sci.aha.ru/econ/A111c.htm. Lesedato 15. august 2016.

Arktisk strategi (2008) «Basics of the State Policy of the Russian Federation in the Arctic for the Period till 2020 and for a further Perspective». Tilgjengelig på http://www.arcticgovernance.org/russia-basics-of-thestate-policy-of-the-russian-federation-in-the-arctic-for-the-period-till-2020-and-for-a-further-perspective. 4651232-142902.html. Lesedato 15. august 2016.

Arktisk strategi (2013) «Strategija razvitija Arktitsjeskoj zony Rossijskoj Federatsii i obespetsjenija natsionalnoj bezopasnosti na period do 2020 goda». Tilgjengelig på http://archive.government.ru/docs/22846/. Lesedato 15. august 2016.

Balzer, Harley (2005) "The Putin Thesis and Russian Energy Policy». Post-Soviet Affairs 21 (3): $210-225$.

Balzer, Harley (2006) «Vladimir Putin's Academic Writings and Russian Natural Resource Policy». Problems of Post-Communism (January/February): 48-54.

Barentsobserver (2015) «Arctic Brigade Trains Counter-Terrorism at Novaya Zemlya» 13. oktober. Tilgjengelig på http://barentsobserver.com/en/security/2015/10/arctic-brigade-trains-counter-terrorism-novaya-zemlya-13-10. Lesedato 15. august 2016.

BP (2016) «BP Energy Outlook - 2016 edition». Tilgjengelig på www.bp.com/content/dam/bp/pdf/energyeconomics/energy-outlook-2016/bp-energy-outlook-2016.pdf. Lesedato 15. august 2016.

Budzik, Philip (2009) "Arctic Oil and Natural Gas Potential» U.S. Energy Information Administration. Tilgjengelig på www.eia.gov/oiaf/analysispaper/arctic/. Lesedato 15. august 2016.

Claes, Dag Harald \& Arild Moe (2014) «Arctic Petroleum Resources in a Regional and Global Perspective» i Rolf Tamnes \& Kristine Offerdal (red.) Geopolitics and Security in the Arctic. London: Routledge $(97-120)$.

CNBC (2016) «Russia will have Exhausted $\$ 87$ Billion Wealth Fund by 2017, amid Oil Price Slide»5. juli. Tilgjengelig på www.cnbc.com/2016/07/05/russia-to-empty-one-of-its-sovereign-funds-next-year--ministryproposal.html. Lesedato 15. august 2016.

Emberland, Torkil (2015) «Norske bedrifter taper ti milliarder på sanksjonene - men Russland eksporterer plutselig masse olje til Norge». Nord24 7. august. Tilgjengelig på www.nord24.no/russland/handel/norskebedrifter-taper-ti-milliarder-pa-sanksjonene-men-russland-eksporterer-plutselig-masse-olje-til-norge/s/5-3235148. Lesedato 15. august 2015.

Energidepartementet (u.d.a) «Crude oil». Tilgjengelig på http://minenergo.gov.ru/en/activity/statistic. Lesedato 1. november 2016 .

Energidepartementet (u.d.b) «Natural gas». Tilgjengelig på http://minenergo.gov.ru/en/activity/statistic. Lesedato 1. november 2016.

Energistrategi (2003) «Energetitsjeskaja strategija Rossii na period do 2020 goda». Tilgjengelig på www. energystrategy.ru/projects/ES-28_08_2003.pdf. Lesedato 15. august 2016.

Energistrategi (2010) «Energy Strategy of Russia - for the period up to 2030». Godkjent i 2009. Tilgjengelig på www.energystrategy.ru/projects/docs/ES-2030_(Eng).pdf. Lesedato 15. august 2016.

Energistrategi, hovedpunkter (2014) «Energetitsjeskaja strategija Rossii na period do 2035 goda (Osnovnye polozjenija)». Tilgjengelig på http://minenergo.gov.ru/node/1913. Lesedato 15. august 2016.

EIA (2012) «New application of existing techniques in old fields helps Russia increase oil production». Tilgjengelig på http://www.eia.gov/todayinenergy/detail.cfm?id=8350. Lesedato 15. august 2016.

EIA (2014) «Oil and natural gas sales accounted for $68 \%$ of Russia's total export revenues in $2014 »$. Tilgjengelig på http://www.eia.gov/todayinenergy/detail.cfm?id=17231. Lesedato 15. august 2016.

EIA (2015) Russia. Tilgjengelig på www.eia.gov/beta/international/analysis_includes/countries_long/Russia/ russia.pdf. Lesedato 15 . august 2016.

EIA (2016) «International Energy Outlook 2016». Tilgjengelig på http:/www.eia.gov/forecasts/ieo/pdf/ 0484(2016).pdf. Lesedato 15. august 2016.

Finansdepartementet (u.d.a) «Debt Structure: Public External Debt of the Russian Federation». Tilgjengelig på http://old.minfin.ru/en/debt/external/structure/?id_4=25614. Lesedato 5. november 2016.

Finansdepartementet (u.d.b) «Volume of the Reserve Fund». Tilgjengelig på http://old.minfin.ru/en/reservefund/ statistics/volume/. Lesedato 5. november 2016. 
Finansdepartementet (u.d.c) «Brief Information on the Federal Budget Execution (bln rub)». Tilgjengelig på http://old.minfin.ru/en/statistics/fedbud/execute/printable.php?id_4=25609. Lesedato 15. august 2016.

Finansdepartementet (u.d.d) «Amount of the National Wealth Fund». Tilgjengelig på http://old.minfin.ru/en/ nationalwealthfund/index.php. Lesedato 5. november 2016.

Finn, Peter (2006) «Oil Profits Help Russia Pay Off Soviet-Era Debt». Washington Post 22. august. Tilgjengelig på www.washingtonpost.com/wp-dyn/content/article/2006/08. Lesedato 15. august 2016.

Fomtsjenkov, Taras (2015) «Minenergo: dobytsja nefti v Arktike vygodna i sejtsjas». Rossijskaja gazeta 24 . juni. Tilgjengelig på www.rg.ru/2015/06/24/arktika2-site-anons.html. Lesedato 15. august 2016.

Franza, Luca (2016) «Developments in Gas Supplies to Europe». CIEP Briefing Paper. March. Tilgjengelig på www. clingendaelenergy.com/files.cfm?event=files.download\&ui=42588E2C-5254-00CF-FD03C86C2995C917. Lesedato 15. august 2016.

Gaidar, Yegor (2007) «The Soviet Collapse: Grain and Oil». American Enterprise Institute for Public Policy research. Tilgjengelig på www.aei.org/wp-content/uploads/2011/10/20070419_Gaidar.pdf. Lesedato 15. august 2016.

Goldman, Marshall I. (2010) Petrostate - Putin, Power, and the New Russia. New York: Oxford University Press.

Godzimirski, Jakub M. (2013) «Introduction: Understanding Russian Energy after the Crisis» i Jakub M. Godzimirski (red.) Russian Energy in a Changing World: What is the Outlook for the Hydrocarbons Superpower? Farnham: Ashgate Publishing Ltd. (1-12).

Goodman, David \& Mark Potter (2016) «UPDATE 2-Russia's Yamal LNG Gets Round Sanctions with \$12 bln Chinese Loan Deal». Reuters 29. april. Tilgjengelig på www.reuters.com/article/russia-china-yamalidUSL5N17W2G8. Lesedato 15. august 2016.

Gustafson, Thane (2012) Wheel of Fortune: The Battle for Oil and Power in Russia. Cambridge: Harvard University Press.

Hakvåg, Una, Kjetil Hove \& Cecilie Sendstad (2012) «Skremmende tall? Realismen i det russiske våpenprogrammet GPV-2020». FFI-rapport 2012/00356.

Henderson, James \& Julia Loe (2014) «The Prospects and Challenges for Arctic Oil Development». Oxford Institute for Energy Studies. Tilgjengelig på www.oxfordenergy.org/wpcms/wp-content/uploads/2014/11/ WPM-56.pdf. Lesedato 15. august 2016.

Henderson, James (2015) «Key Determinants for the Future of Russian Oil Production and Exports». Oxford Institute for Energy Studies. Tilgjengelig på www.oxfordenergy.org/wpcms/wp-content/uploads/2015/04/ WPM-58.pdf. Lesedato 15. august 2016.

IEA (2014) «Russia 2014 - Energy Policies Beyond IEA Countries». Tilgjengelig på www.iea.org/publications/ freepublications/publication/Russia_2014.pdf. Lesedato 15. august 2016.

Ilulissaterklæringen (2008) Tilgjengelig på www.arcticgovernance.org/the-ilulissat-declaration.4872424.html. Lesedato 15. august 2016.

Konyshev, Valery \& Alexander Sergunin (2014) «Is Russia a Revisionist Military Power in the Arctic?». Defence E Security Analysis 30 (4): 323-335.

Kreml (2007) «Press Statement and Responses to Media Questions Following the Peace Mission 2007 Counterterrorism Exercises and the Shanghai Cooperation Organisation Summit» 17. august. Tilgjengelig på http://en.kremlin.ru/events/president/transcripts/24475. Lesedato 15. august 2016.

Kreml (2008) «Speech at Meeting of the Russian Security Council on Protecting Russia's National Interests in the Arctic» 17. september. Tilgjengelig på http://en.kremlin.ru/events/president/transcripts/48304. Lesedato 15. august 2016.

Kreml (2014) «Meeting of the Security Council on state policy in the Arctic» 22. april. Tilgjengelig på http://en. kremlin.ru/events/president/news/20845. Lesedato 15. august 2016.

Kryukov, Valerij \& Arild Moe (2006) «Hydrocarbon Resources and Northern Development» i Helge Blakkisrud \& Geir Hønneland (red.) Tackling Space: Federal Politics and the Russian North. Lanham: University Press of America (123-141).

Kryukov, Valerij \& Arild Moe (2013) «Oil Industry Structure and Developments in the Resource Base: Increasing Contradictions?» i Jakub M. Godzimirski (red.) Russian Energy in a Changing World: What is the Outlook for the Hydrocarbons Superpower? Farnham: Ashgate Publishing Ltd. (35-55).

Laruelle, Marlene (2014) Russia's Arctic Strategies and the Future of the Far North. Armonk, New York: M.E. Sharpe.

Lowe, Christian \& Katya Golubkova (2016) «Russia Will Cut Defense Budget by 5 Percent in 2016, RIA Reports». Reuters 6. mars. Tilgjengelig på www.reuters.com/article/us-russia-defense-budgetidUSKCNOW80TL. Lesedato 15. august 2016.

Luomi, Mari (2016) «Is the Paris Agreement a Success and What Does it Mean for the Energy Sector?». Oxford Energy Forum. Tilgjengelig på www.oxfordenergy.org/wpcms/wp-content/uploads/2016/06/OEF-105.pdf. Lesedato 15. august 2016. 


\section{ANN KARIN LARSSEN}

Miller, Chris (2016) «COMMENT: Russia's Central Bank: Giving Credit where Credit is Due». Bne intellinezws 16. mai. Tilgjengelig på www.intellinews.com/comment-russia-s-central-bank-giving-credit-where-credit-isdue-97502/. Lesedato 15. august 2016.

Moe, Ingeborg \& Alf Ole Ask (2014) «Sanksjoner stanser ikke russernes oljejakt i Norge». Aftenposten 25. september. Tilgjengelig på www.aftenposten.no/verden/Sanksjoner-stanser-ikke-russernes-oljejakt-iNorge-583042b.html. Lesedato 15. august 2016.

Militærdoktrinen (2014) «Vojennaja doktrina Rossijskoj Federatsii». Rossijskaja gazeta 30. desember. Tilgjengelig på www.rg.ru/2014/12/30/doktrina-dok.html. Lesedato 15. august 2016.

Nasjonale sikkerhetsstrategi (2015) «Strategija natsionalnoj bezopasnosti Rossijskoj Federatsii». Rossijskaja gazeta 31.desember. Tilgjengelig på https://rg.ru/2015/12/31/nac-bezopasnost-site-dok.html. Lesedato 15. august 2016.

NATO (2016) «Warsaw Summit Communique» 9. juli. Tilgjengelig på www.nato.int/cps/en/natohq/official_ texts_133169.htm?selectedLocale=en. Lesedato 15. august 2016.

New York Times (1989) «Soviet Military Budget: \$128 Billion Bombshell» 31. mai. Tilgjengelig på www. nytimes.com/1989/05/31/world/soviet-military-budget-128-billion-bombshell.html. Lesedato 15. august 2016.

Orttung, Robert W. \& Indra Øverland (2011) «A Limited Toolbox: Explaining the Constraints on Russia's Foreign Energy Policy». Fournal of Eurasian Studies 2: 74-85.

Pettersen, Trude (2016) «Rosneft and Statoil Start Well Testing in Siberia». The Independent Barents Observer 8. februar. Tilgjengelig på http://thebarentsobserver.com/industry/2016/02/rosneft-and-statoil-start-welltesting-siberia. Lesedato 15. august 2016.

Pinchuk, Denis \& Olesya Astakhova (2015) «Exclusive: Russia’s Rosneft Unlikely to Resume Kara Sea Drilling Before 2018 - Sources». Reuters 11. juni. Tilgjengelig på www.reuters.com/article/us-russia-rosneft-karasea-idUSKBN0OR16H20150611. Lesedato 15. august 2016.

Pismennaya, Evgenia \& Anna Andrianova (2016) «Russia's Economy Is Tanking, So Why Is Putin Smiling?» Bloomberg 1. mars. Tilgjengelig på www.bloomberg.com/news/articles/2016-03-01/as-russia-s-economycontracts-putin-s-preferred-indicator-is-up. Lesedato 15. august 2016.

Ramsdal, Roald (2013) «Fedynskyhøyden - Dette kan bli prøvesteinen på samarbeidet Norge-Russland». Teknisk Ukeblad 13.november. Tilgjengelig på www.tu.no/artikler/dette-kan-bli-provesteinen-pa-samarbeidet-norge-russland/233908. Lesedato 15 . august 2016.

Rapoza, Kenneth (2015) «Here’s Where Russia Shipped Oil Last Year as Ukraine, Europe Diversified». Forbes 7. april. Tilgjengelig på www.forbes.com/sites/kenrapoza/2015/04/07/heres-where-russia-shipped-oil-lastyear-as-ukraine-europe-diversifies/\#1d3da0045ed8. Lesedato 15. august 2016.

RBTH (2016) «The Volume of Russia's Foreign Debt Decreases by $\$ 83.7$ Billion in 2015» 25. januar. Tilgjengelig på http://rbth.com/business/2016/01/25/the-volume-of-russias-foreign-debt-decreases-by837-billion-in-2015_562121. Lesedato 15. august 2016.

Regjeringen, Norge (2016a) «Tildeling av leteareal i 23. konsesjonsrunde»18. mai. Tilgjengelig på www. regjeringen.no/no/aktuelt/23.-konsesjonsrunde-tildeling/id2500. Lesedato 15. august 2016.

Regjeringen, Norge (2016b) «Kart over tildelte utvinningstillatelser». www.regjeringen.no/contentassets/ e4186b93baf8420b815261353fc4884a/vedlegg-1-kart-over-tildelte-utvinningstillatelser-nor.pdf. Lesedato 15. august 2016 .

RT (2013) «Russian Military Resumes Permanent Arctic Presence» 14. september. Tilgjengelig på www.rt. com/news/russian-arctic-navy-restitution-863/. Lesedato 15. august 2016.

Sabitova, Nadia \& Chulpan Shavaleyeva (2015) «Oil and Gas Revenues of the Russian Federation: Trends and Prospects». Procedia Economics and Finance 27: 423-428. Tilgjengelig på http://ac.els-cdn.com/ S2212567115010163/1-s2.0-S2212567115010163-main.pdf?_tid=ae39d826-62fb-11 e6-bbb5-00000aab 0f01\&acdnat=1471274558_8dcdabdfe11e609f031339341dd48e00. Lesedato 15. august 2016.

Sentralbanken (u.d.a) «Russian Federation: Crude Oil Exports, 2000-2016». Excel-ark. Tilgjengelig på www. cbr.ru/eng/statistics/?Prtid=svs. Lesedato 15. august 2016.

Sentralbanken (u.d.b) «International Reserves of the Russian Federation». Excel-ark. Tilgjengelig på www.cbr. ru/eng/statistics/?Prtid=svs. Lesedato 5. november 2016.

Sentralbanken (u.d.c) «Merchandise Trade of the Russian Federation». Excel-ark. Tilgjengelig på www.cbr.ru/ eng/statistics/?Prtid=svs. Lesedato 15 . august 2016.

Sentralbanken (u.d.d) «Russian Federation: Natural Gas Exports, 2000-2016». Excel-ark. Tilgjengelig på www.cbr.ru/eng/statistics/?Prtid=svs. Lesedato 15. august 2016.

Sipri (2016) «Trends in World Military Expenditure, 2015». Tilgjengelig på www.sipri.org/sites/default/files/ EMBARGO\%20FS1604\%20Milex\%202015.pdf. Lesedato 15. august 2016. 
Sputniknews (2015) «Russia to Reconstruct 10 Military Airfields in Arctic by Year's End» 13. januar. Tilgjengelig på http://sputniknews.com/military/20150113/1016832361.html. Lesedato 15. august 2016.

Staalesen, Atle (2014) «FSB Trains Counter-Terrorism at Arctic Oil Installation». Barentsobserver 17. juni. Tilgjengelig på http://barentsobserver.com/en/security/2014/06/fsb-trains-counter-terrorism-arctic-oilinstallation-17-06. Lesedato 15. august 2016.

Staalesen, Atle (2015) «Russia Ready to Talk with Denmark over North Pole». Barentsobserver 5. august. Tilgjengelig på http://barentsobserver.com/en/arctic/2015/08/russia-ready-talk-denmark-over-north-pole05-08. Lesedato 15. august 2016.

Staalesen, Atle (2016) «50 Million Tons of Russian Arctic Oil». The Independent Barents Observer 3. februar. Tilgjengelig på http://thebarentsobserver.com/industry/2016/02/50-million-tons-russian-arctic-oil. Lesedato 15. august 2016 .

Statoil (2009) «Snøhvit: ny energihistorie i kalde nord». Tilgjengelig på www.statoil.com/no/OurOperations/ ExplorationProd/ncs/Pages/SnohvitNewEnergyHistoryInTheNorth.aspx. Lesedato 15. august 2016.

Statoil (2012) «Statoil inngår samarbeidsavtale med Rosneft». Tilgjengelig på www.statoil.com/no/NewsAnd Media/News/2012/Pages/StatoilRosneftMay2012.aspx. Lesedato 15. august 2016.

Statoil (2014) «Gassfunn i Pingvin». Tilgjengelig på www.statoil.com/no/NewsAndMedia/News/2014/Pages/ 26Sept_GasFindPingvin.aspx. Lesedato 15. august 2016.

Tass (2016) «Average Price for Urals Crude Oil up $\$ 6$ in March to $\$ 36.53$ Per Barrel - Finance Ministry» 1. april. Tilgjengelig på http://tass.ru/en/economy/866545. Lesedato 15. august 2016.

Teigen, Christer (2015) «Russisk milliardær blir norsk oljebaron». Dagbladet 18. oktober. Tilgjengelig på www. dagbladet.no/2015/10/18/nyheter/okonomi/hegnarno/eon/fridman/41558749/. Lesedato 5. november 2016.

Topoilnews (u.d.) «Urals Oil Price». Tilgjengelig på www.topoilnews.com/. Lesedato 15. august 2016.

Trading economics (u.d.a) «Russia Government Debt to GDP 1999-2016». Tilgjengelig på www.tradinge conomics.com/russia/government-debt-to-gdp. Lesedato 15. august 2016.

Trading economics (u.d.b) «Russia Government Budget 1994-2016». Tilgjengelig på http://www.trading economics.com/russia/government-budget. Lesedato 5. november 2016.

Tykkylainen, Markku (2003) «North-West Russia as a Gateway in Russian Energy Geopolitics». Fenna International fournal of Geography 181 (2): 145-177. Tilgjengelig på http://ojs.tsv.fi/index.php/fennia/ article/view/3751. Lesedato 15. august 2016.

USGS (2008) «Circum-Arctic Resource Appraisal: Estimates of Undiscovered Oil and Gas North of the Arctic Circle». Tilgjengelig på http://pubs.usgs.gov/fs/2008/3049/fs2008-3049.pdf. Lesedato 15. august 2016.

Utenriksdepartementet, Norge (2014) «Forskrift om endring i forskrift 15. august $2014 \mathrm{nr} .1076$ om restriktive tiltak vedrørende handlinger som undergraver eller truer Ukrainas territorielle integritet, suverenitet, uavhengighet og stabilitet. Kgl. res. 10. oktober». Tilgjengelig på www.regjeringen.no/contentassets/ 09b4b60d9ccb4067b489e8effd87e64d/kongeligres_141010.pdf. Lesedato 15. august 2016.

Utkast til Energistrategi (2015) «Projekt. Energetitsjeskaja strategija Rossii na period do 2035 goda» 30. september. Tilgjengelig på http://minenergo.gov.ru/node/1920. Lesedato 15. august 2016.

Verdensbanken (u.d.a) «GDP (Growth annual \%)». Tilgjengelig på http://data.worldbank.org/indicator/NY. GDP.MKTP.KD.ZG?locations=RU. Lesedato 15. august 2016.

Verdensbanken (u.d.b) «Overview Russia». April 2016. Tilgjengelig på www.worldbank.org/en/country/russia/ overview. Lesedato 15. august 2016.

Aale, Per Kristian (2014) «Norge hardest rammet av russiske sanksjoner». Aftenposten 14. august. Tilgjengelig på www.aftenposten.no/okonomi/Norge-hardest-rammet-av-russiske-sanksjoner-583138b.html. Lesedato 15. august 2016 .

Åslund, Anders (2013) «Russia's Economic Transformation» i Michael Alexeev \& Shlomo Weber (red.) The Oxford Handbook of The Russian Economy. New York: Oxford University Press (86-101). 